
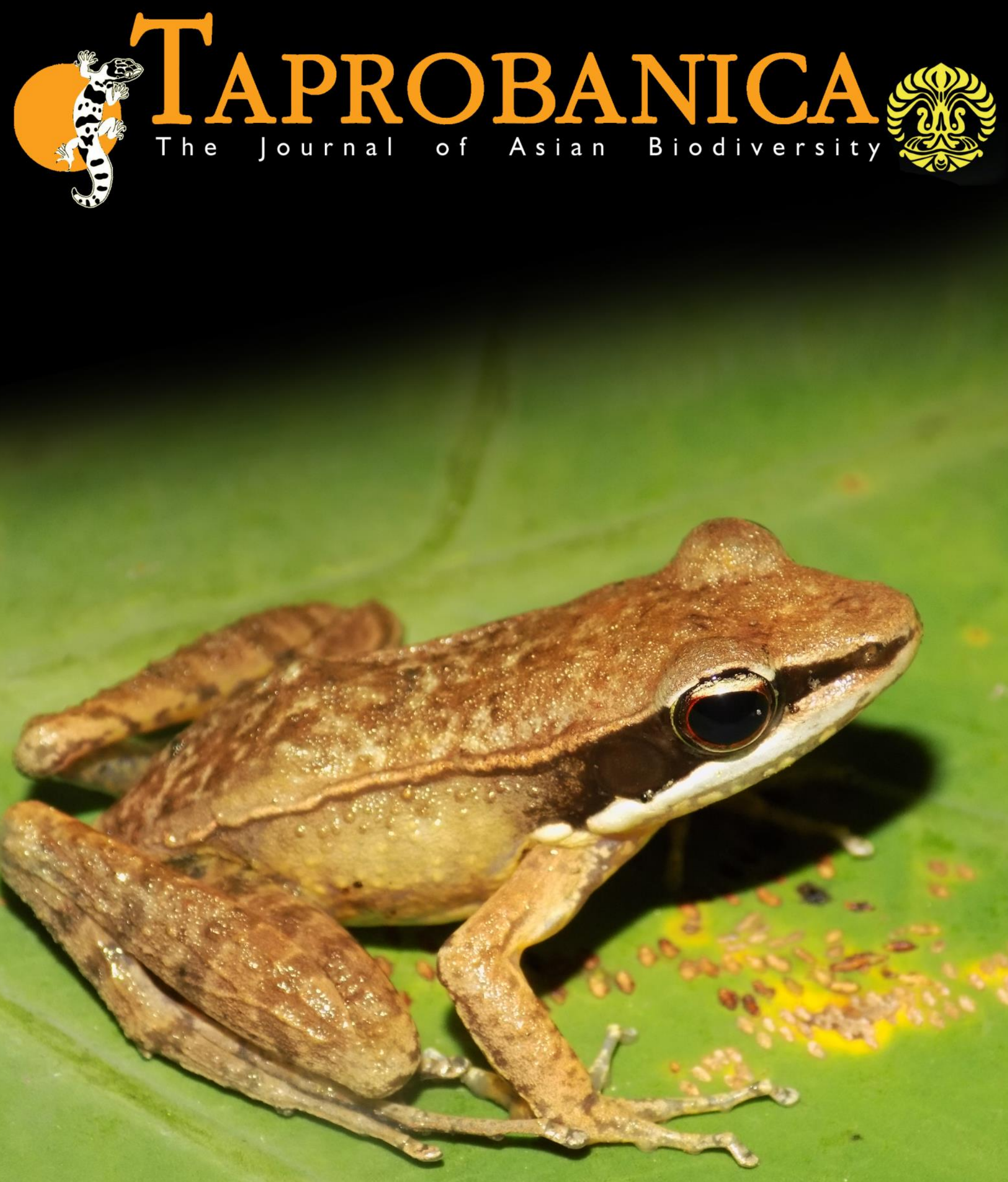
TAPROBANICA, ISSN 1800-427X. September, 2020. Vol. 09, No. 01, Supp. 01: pp. 121-132, pls. $43-45$.

(C) Research Center for Climate Change, University of Indonesia, Depok, Indonesia www.taprobanica.org

\title{
A REASSESSMENT OF THE SYSTEMATIC POSITION OF THE ASIAN RANID FROG Hylorana nicobariensis STOLICZKA, 1870 (AMPHIBIA: ANURA) WITH THE DESCRIPTION OF A NEW GENUS
}

\author{
S.R. Chandramouli ${ }^{1}$, Amir Hamidy ${ }^{2}$ \& A.A. Thasun Amarasinghe ${ }^{3}$ \\ ${ }^{1}$ Department of Ecology and Environmental Sciences, School of Life Sciences, Pondicherry University, \\ Puducherry, India. \\ ${ }^{2}$ Research Center for Biology, Museum Zoologicum Bogoriense, Laboratory of Herpetology, Indonesian \\ Institute of Sciences, Jakarta, Indonesia. \\ ${ }^{3}$ Research Center for Climate Change, Multidisciplinary Lab, FMIPA Building, $7^{\text {th }}$ Floor, Kampus UI, \\ University of Indonesia, Depok 16424, Indonesia. \\ ${ }^{3}$ Association of Asian Herpetology (Asosiasi Herpetologi Asia), Jl. BSD Bintaro No. 88, Pondok Aren 15228, \\ Tangerang Selatan, Indonesia. \\ ${ }^{1}$ Corresponding author. E-mail: findthesnakeman@gmail.com
}

\begin{abstract}
We reassessed the systematic position of the ranid frog Hylorana (=Hylarana) nicobariensis that, owing to its uncertain phylogenetic position and lack of clear morphological characterisation, has lately been allocated to various Asian and African frog genera such as Rana, Sylvirana, Hylarana, Amnirana, and most recently to Indosylvirana. Based on an integrative approach of both phylogenetic and morphological affinities, we describe a new genus to accommodate Hylorana (=Hylarana) nicobariensis and redescribe the species based on new topotypic material from the Nicobar Islands.
\end{abstract}

Key words: Amnirana, Indosylvirana, phylogeny, Southeast Asia, Sundaland, taxonomy

\section{Introduction}

The cosmopolitan frog family Ranidae Batsch, 1796 currently comprises 26 genera and ranges in distribution from North and Central America, Europe, Asia and Africa excluding the southern parts of South America, South Africa and Australia (Frost 2020). Among these 15 genera, namely Abavorana, Amolops, Chalcorana, Clinotarsus, Huia, Humerana, Hydrophylax, Hylarana, Indosylvirana, Merystogenis, Nidirana, Odorrana, Papurana, Pseudorana and Pterorana, occur in the Oriental realm (Frost 2020, Chan et al. 2020). The incorrect spelling of the original description of Hylarana Tschudi, 1838 made by Günther (1864) was corrected by Van Kampen (1923) in the account of nicobariensis. The Sundaic frog Hylorana (= Hylarana) nicobariensis was firstly moved to the genus Rana by Boulenger (1884).

A systematic classification of true frogs of the genus Rana Linnaeus, 1758 was carried out by Dubois (1992) who divided the genus into six 
genera comprising several new subgenera including Chalcorana, Humerana, Papurana, Sylvirana and Amnirana. Dubois (1992) placed the sub-Saharan African ranid frogs into Amnirana, with Rana amnicola Perret, 1977 as the type species, and assigned the Nicobarese species, Hylorana nicobariensis Stoliczka, 1870 to a South and Southeast Asian genus, Sylvirana, which was considered as the most appropriate placement for this species at that time. Frost et al. (2006) followed Dubois (1992) and placed Rana (Sylvirana) nicobariensis under Sylvirana while raising the subgenus to a distinct generic level. However, Che et al. (2007) included Sylvirana members within Hylarana. Based on phylogenetic evidence, Oliver et al. (2015) later reassigned $H$. nicobariensis to Amnirana. Furthermore, in their study on ranid frogs, they elevated several of the sub-genera defined by Dubois (1992) into distinct genera.

The subsequent allocation of this species to an African genus Amnirana by Oliver et al. (2015) was disputed by Chan \& Brown (2017) who showed that the Asian species 'Amnirana' nicobariensis is not sister to the African Amnirana but possibly more closely related to the Asian genera such as Hydrophylax, Indosylvirana, Pulchrana and Sylvirana. Chan et al. (2020) provisionally allocated this species to the largely south Asian genus Indosylvirana, although with some caution, owing to the inconsistency of its phylogenetic position. Although several of the above studies have discussed the generic placement of Hylorana nicobariensis, an unequivocal consensus on its generic placement has not been arrived at. Additionally, most of these studies were based solely on phylogenetic clues and not many of the above studies have backed-up their conclusions with support from morphological or other evidence.

Currently this Asian species (sensu lato) is distributed in the Nicobar Islands, Greater Sunda Islands, Philippines, as well as Islands in the Sulu Archipelago (Oliver et al. 2015). Herein, we reassess the available phylogenetic evidence concerning Hylorana nicobariensis and resolve the problem of its inconsistent generic placement by erecting a new genus for this Southeast Asian species.

\section{Material and methods}

Field survey and specimen collection: Adult specimens were observed at night, mostly by locating calling males, and sometimes by opportunistic surveys during both day and night. Live frogs were photographed in the wild. Topotypic specimens collected from the Nicobar Islands are deposited in the Department of Ocean Studies and Marine Biology, Pondicherry University campus at Port Blair (DOSMB), India. The specimens collected from West Java are deposited in the Museum of Zoology, Research Center for Climate Change, University of Indonesia (UIMZ). Comparative materials are given in Appendix I. A Garmin GPSMAP 78s was used to record GPS coordinates in the field. Calls were recorded with a Samsung Galaxy mobile phone using the audio recorder application and analysed with Adobe Soundbooth CS3.

Phylogenetic analysis: For the phylogenetic study, DNA sequences from previously published studies were retrieved for four genes (two mitochondrial: 16S rRNA and Cytb; two nuclear: Rag1 and Tyrosinase) representing the type species of all of the presently recognised 26 ranid genera (except Pterorana), including a population of "Amnirana" nicobariensis from Sumatra, with Limnonectes laticeps as the outgroup taxon (Table 1). The individual gene sequences were retrieved and aligned using ClustalW in MEGA 6.06 (Tamura et al. 2013). The best fitting DNA substitution model for each gene was determined by using Akaike Information criterion (AIC), as implemented in JModelTest3.5 (Posada \& Crandall 1998). The alignments were concatenated to get a final single dataset of $2132 \mathrm{bp}$ and subjected to phylogenetic analysis in the Bayesian framework, conducted using the inferred GTR $+\mathrm{G}+\mathrm{I}$ base substitution model for each gene partition.

The Bayesian inference (BI) was implemented in MrBayes 3.1.2 (Ronquist \& Huelsenbeck 2003) using the following parameters: GTR+G+I model of DNA substitution, Nst as 6 (all different substitution rates subjected to GTR), 10,000,000 MCMC iterations in two runs and four chains; with sampling at every 1000 iterations; stationarity of the runs determined by minimum standard deviation of the split frequencies 0.01 ; and burnin of initial $25 \%$ of stored trees. The output trees were visualized using Figtree (http://tree.bio.ed.ac.uk/software/figtree/). For comparison based on genetic distances between all the ranid genera, uncorrected pairwise distances were calculated for the partial $16 \mathrm{~S}$ rRNA gene in MEGA 6.06 (Tamura et al. 2013). 


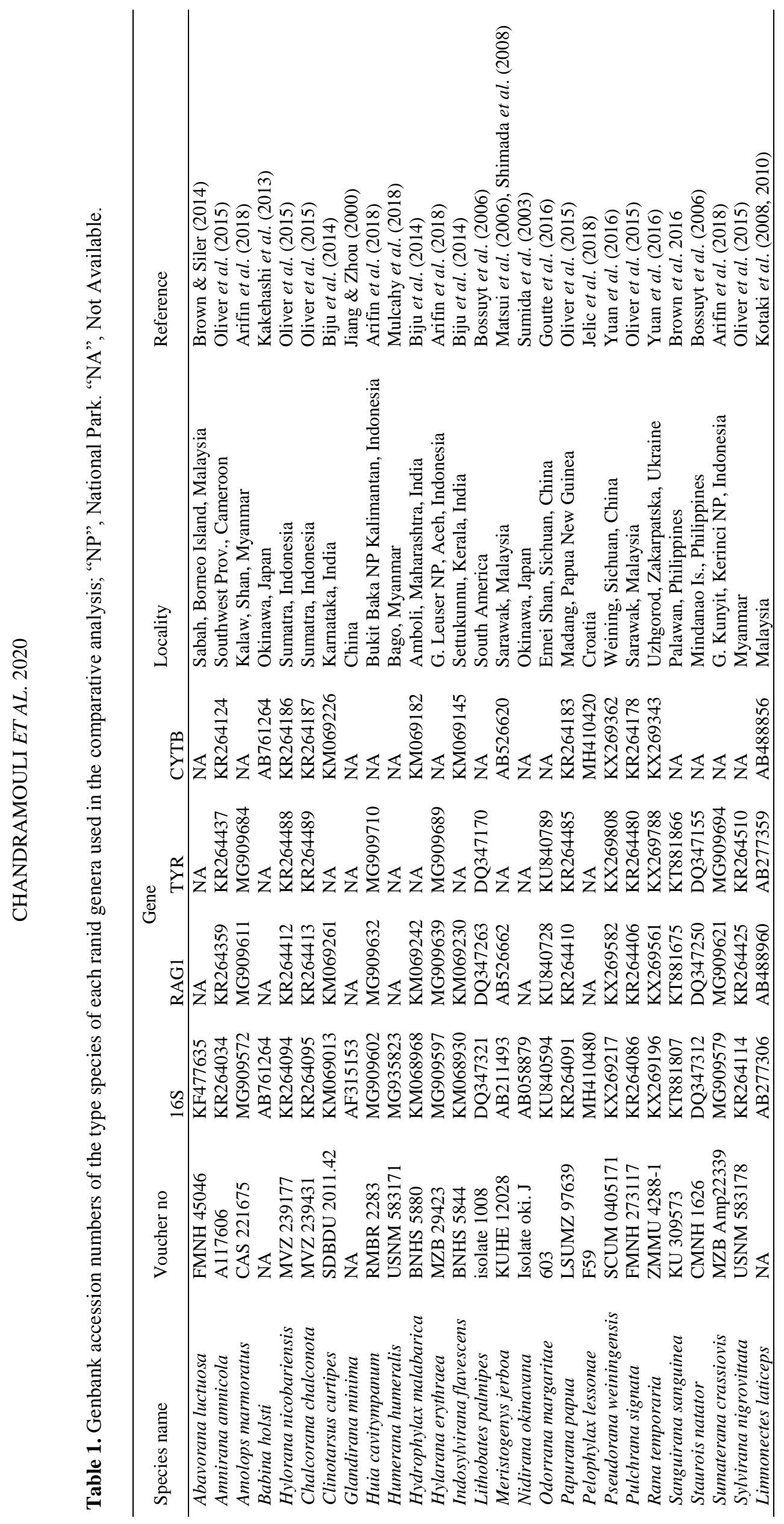




\section{A NEW ASIAN RANID FROG GENUS}

Morphology and recognition of new genus: Our study adopted an integrative approach in recognizing a new genus based on molecular and morphological data. The candidate genus was compared with all available types of type species, recently collected specimens or original descriptions of other Asian ranid genera (Table 2). Museum acronyms are those of Uetz et al. (2019). Sex and maturity were determined by examining gonads through a small ventral incision and based on secondary sexual characters such as presence or absence of nuptial pads on the first finger. Only mature (adult) animals were used for morphological analysis, species comparisons. Webbing formula follows Savage \& Heyer (1967). The syntypes (ZSIC 2783, 2785-86, 3562-63, 3565-70) of Hylorana nicobariensis were studied at the Zoological Survey of India, Kolkata. Measurements of Indian (Nicobarese) specimens were taken by SRC and Indonesian specimens were taken by AATA. Under an AmScope SM-1BZ-RL dissecting microscope, with a Mitutoyo digital caliper to the nearest $0.1 \mathrm{~mm}$, we measured snout-vent length (SVL, from the tip of the snout to the anterior margin of the cloaca), axilla-groin length (AG, from the posterior margin of the forelimb at its insertion point on the body to the anterior margin of the hind limb at its insertion point on the body), head length
(HL, from the posterior edge of the mandible to the tip of the snout), head width (HW, the maximum width of the head at the angle of the jaws), head depth (HD, the maximum depth of the head), eye diameter (ED, the greatest horizontal diameter of the orbit), eye-nostril length (EN, from the anterior border of the orbit to the middle of the nostril), snout length (ES, from the anterior border of the orbit to the tip of the snout), tympanum-eye length (TYE, from the posterior border of the orbit to the anterior border of the tympanum), upper eyelid width (UEW, the maximum width of the upper eyelid), inter-orbital distance (IO, distance between the upper eyelids), inter-narial distance (IN, distance between the nostrils), tympanum diameter (TYD, the greatest horizontal diameter of the tympanum), upper arm length (UAL, from the axilla to elbow), lower arm length (LAL, from the posterior margin of the elbow to the base of the outer metacarpal tubercle), palm length (PAL, from the posterior border of the outer metacarpal tubercle to tip of the 3rd finger), femur length (FEL, from the cloaca to the knee), tibia length (TBL, from knee to heel), tarsus length (TSL, from heel to inner metatarsal tubercle), foot length (FOL, from inner metatarsal tubercle to the tip of the 4th toe). Digit number is represented by roman numerals I-V.

Table 2. Character comparisons across Asian and African ranid genera highlighting the distinction of the new genus (modified after Oliver et al. 2015).

\begin{tabular}{|c|c|c|c|c|c|c|c|c|c|}
\hline Character & 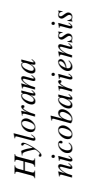 & 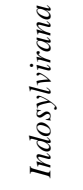 & 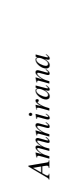 & 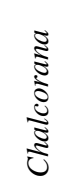 & 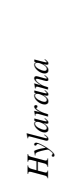 & 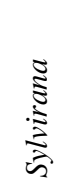 & 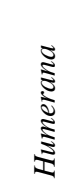 & 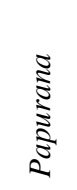 & 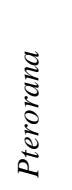 \\
\hline $\begin{array}{l}\text { Posterior part of abdominal skin smooth (0), wrinkled } \\
\text { (1), granular (2) }\end{array}$ & 0 & 1,2 & 0,2 & 2 & 0,1 & 0,2 & 0,1 & 0 & 2 \\
\hline Length comparison: finger I and II & $\mathrm{I}>\mathrm{II}$ & $\mathrm{I}>\mathrm{II}$ & $\mathrm{I} \geq \mathrm{II}$ & $\mathrm{I}<\mathrm{II}$ & $\mathrm{I}=\mathrm{II}$ & $\mathrm{I}>\mathrm{II}$ & $\mathrm{I}>\mathrm{II}$ & $\mathrm{I}>\mathrm{II}$ & $\mathrm{I}>\mathrm{II}$ \\
\hline $\begin{array}{l}\text { Dorsolateral fold indistinct (0), weakly distinct (1), } \\
\text { markedly-distinct (2) }\end{array}$ & 2 & 1,2 & $\begin{array}{c}0, \\
1,2\end{array}$ & 0 & 1 & $\begin{array}{c}0, \\
1,2\end{array}$ & 2 & 1,2 & 2 \\
\hline $\begin{array}{l}\text { Dorsolateral fold colour paler than dorsal colour ( } 0 \text { ), } \\
\text { uniform with dorsum (1) }\end{array}$ & 1 & 0 & 1 & 1 & 0 & 1 & 1 & 1 & 1 \\
\hline Outer metatarsal tubercle absent ( 0$)$, present (1) & 1 & 1 & 0,1 & 0,1 & 1 & 1 & 0,1 & 1 & 1 \\
\hline $\begin{array}{l}\text { If present, outer metatarsal tubercle small }(0) \text {, medium } \\
(1) \text {, large (2) in size }\end{array}$ & 1 & 2 & 0,1 & 0 & 1 & 1 & 0 & 0,1 & 1 \\
\hline Digital disc shape ovoid (0), rhomboid (1) & 0 & 0 & 0 & 1 & 0 & 0 & 0 & 0 & 0 \\
\hline $\begin{array}{l}\text { Flank colouration uniform with dorsum (0), darker (1), } \\
\text { mottled (2), bicoloured (3) }\end{array}$ & 0 & 0 & 2 & 0 & $\begin{array}{c}1, \\
2,3\end{array}$ & 1 & $\begin{array}{l}0, \\
1,2\end{array}$ & 0,2 & 1 \\
\hline $\begin{array}{l}\text { Thigh colour pattern uniform with dorsum ( } 0) \text {, banded } \\
\text { (1), mottled (2), bicoloured ( } 3 \text { ) }\end{array}$ & 1 & 1 & 2 & 0 & $\begin{array}{c}0, \\
2,3\end{array}$ & 2 & 0,2 & 0,2 & 1 \\
\hline $\begin{array}{l}\text { Hind limb colour pattern uniform with dorsum (0), } \\
\text { banded (1), mottled (2), bicoloured (3) }\end{array}$ & 1 & 1 & 2 & 0 & $\begin{array}{c}0, \\
2,3\end{array}$ & 1 & 0,2 & 0,1 & 1 \\
\hline Rictal ridge broken $(0)$, continuous ( 1 ) & 1 & 1 & 1 & 1 & 1 & 1 & 0,1 & 0,1 & 1 \\
\hline $\begin{array}{l}\text { If continuous, rictal ridge weakly or moderately } \\
\text { developed }(0) \text {, well-developed (1) }\end{array}$ & 1 & 0 & 1 & 0 & 1 & 0 & 1 & 0 & 1 \\
\hline
\end{tabular}




\section{Results}

Phylogenetic analysis: The phylogenetic analysis based on four genes shows the distinctiveness and unique taxonomic position of Hylorana nicobariensis within the family Ranidae. Our Bayesian analysis recovered Hylorana nicobariensis as a sister taxon to the southeast Asian clade comprising the genera Sylvirana + (Hylarana + Humerana $)$ with moderate support $(0.78 \mathrm{BPP})$, rather than the African genus Amnirana or south Asian genus Indosylvirana as proposed by Oliver et al. (2015) and Chan et al. (2020), respectively. For the mitochondrial 16S, Hylorana nicobariensis also showed the least genetic divergence from Sylvirana nigrovittata $(13.64 \%)$ than the other ranid genera (Table 3). Specifically, from Indosylvirana, under which Chan et al. (2020) provisionally attributed this taxon, it showed a comparatively much higher genetic divergence $(19.31 \%)$, which was almost at the higher end of the range within Ranidae (13.64-24.03\%; Table 3 ; Figs. 1, 2). The Bayesian analysis also recovered the genus Amnirana as the sister group to Indosylvirana, with weak support. The sister relationship between Amnirana and Indosylvirana presented here is consistent with that of Chan \& Brown (2017) but deviates from the relationship shown by Chan et al. (2020) and Oliver et al. (2015). Likewise, the sister relationship between the genera Hylarana and Humerana observed in our study is largely consistent with most of the recently published ranid phylogenies (Oliver et al. 2015; Chan \& Brown 2017; Chan et al. 2020). However, the relationships of the focal taxon Hylorana nicobariensis with other ranid genera have not been consistent. Altogether, our phylogenetic analysis clearly shows that Hylorana nicobariensis is not closely related to either Indosylvirana as implied by Chan et al. (2020) or Amnirana as suggested by Oliver et al. (2015), necessitating the erection of a new monotypic genus to accommodate Hylorana nicobariensis and stabilize its taxonomic status.

\section{Taxonomy}

Ranidae Batsch, 1796

The generic names Calamita Oken, 1816 (now a synonym of Epidalea Cope, 1864: type species: Bufo calamita Laurenti, 1768) and Auletris Wagler, 1830 (now a synonym of Boana Gray, 1825, type species: Rana boans Linnaeus, 1758) under which, Hyla bilineata Van Ernest in Daudin, 1800, a senior synonym of Hylorana nicobariensis Stoliczka, 1870 was once attributed (fide Frost, 2020) are now currently allocated to Hylidae Rafinesque, 1815 hence, unavailable for allocation (vide Art. 23 of the ICZN 1999). All the specimens of the syntypes series (11 specimens) of Hylorana nicobariensis consisting of adult and larval specimens belong to the same species. Therefore, we measured only one syntype (ZSI 2783; see Table 4). Among the type series only few specimens (including the one measured) are in a relatively good condition. The rest have broken limbs. The fresh topotypes used in this study were compared carefully with all the syntypes and confirmed alike. Therefore, here we use fresh topotypes for the redescription.

Table 3. Genetic divergence (in \%) of Hylorana nicobariensis from the type species of other ranid genera based on 16s rRNA gene.

\begin{tabular}{|c|c|c|c|c|c|}
\hline Type species & 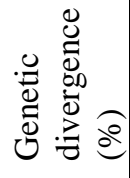 & Type species & 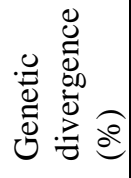 & Type species & 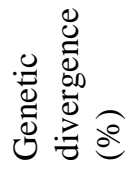 \\
\hline Sylvirana nigrovittata & 13.64 & Huia cavitympanum & 15.50 & Rana temporaria & 17.75 \\
\hline Lithobates palmipes & 13.64 & Sumaterana crassiovis & 16.00 & Amnirana amnicola & 17.96 \\
\hline Papurana papua & 13.85 & Odorrana margaretae & 16.00 & Sylvirana nigrovittata & 18.10 \\
\hline Pseudorana weiningensis & 13.85 & Abavorana luctuosa & 16.74 & Papurana рариа & 18.12 \\
\hline Humerana humeralis & 14.90 & Amolops marmoratus & 16.74 & Humerana humeralis & 18.42 \\
\hline Chalcorana chalconota & 14.90 & Lithobates palmipes & 16.95 & Babina holsti & 18.54 \\
\hline Babina holsti & 15.16 & Indosylvirana flavescens & 16.95 & Hylarana erythraea & 18.74 \\
\hline Pelophylax lessonae & 15.16 & Pseudorana weiningensis & 17.12 & Hydrophylax malabarica & 19.16 \\
\hline Hylarana erythraea & 15.26 & Limnonectes laticeps & 17.12 & Meristogenys jerboa & 19.19 \\
\hline Nidirana okinavana & 15.26 & Glandirana minima & 17.37 & Sumaterana crassiovis & 19.31 \\
\hline Hydrophylax malabarica & 15.30 & Staurois natator & 17.37 & Abavorana luctuosa & 20.95 \\
\hline Sanguirana sanguinea & 15.30 & Clinotarsus curtipes & 17.50 & & \\
\hline Meristogenys jerboa & 15.50 & Pulchrana signata & 17.54 & & \\
\hline
\end{tabular}




\section{A NEW ASIAN RANID FROG GENUS}

\section{Bijurana gen. nov.}

[urn:Isid:zoobank.org:act:5515C691-3EBB-4B95-8F76051C01A2FDB5]

Type species: Hylorana nicobariensis Stoliczka, 1870 by present designation

Content: Bijurana nicobariensis (Stoliczka, 1870) comb. nov.

Syntypes $(\boldsymbol{n}=11)$ : ZSIC 2783, 2785-86, 3562-63, 3565-70 collected from "Nicobar Is.", India.

Etymology. The generic epithet is a patronym honoring Prof. Sathyabhama Das Biju (University of Delhi, India), for his enormous contributions to amphibian research and conservation in the Indian subcontinent. Prof. Biju is renowned as "the frogman of India" for bringing fresh fascination for Indian amphibians.

Diagnosis and definition. (Figs. 1, 3, 6, 7; Table 2). In a phylogenetic framework, the new genus described below is currently monotypic in the family Ranidae that includes the species
Hylorana nicobariensis, but not the type species of any of the currently recognised, closely related ranid genera Sylvirana, Humerana, Hylarana, Indosylvirana, Amnirana, Hydrophylax, Papurana, Chalcorana, or Pulchrana.

Morphologically, the new genus Bijurana is characterized by the following combination of characters: medium to large body size (SVL 37.0-53.0 mm); smooth abdominal skin; finger I $>$ II; thighs with banded pattern and longitudinal skin folds; pronounced dorsolateral folds; presence of eight presacral vertebrae with horizontally elongated hypapophyses; firmisternal pectoral girdle; sacral diapophysis not flattened or expanded laterally; urostyle lacking lateral dilations; presence of vomerine teeth; presence of large and exposed tympanum; presence of rictal glands; absence of elongated ventrolateral glands; digit tips mildly dilated with expanded, ovoid terminal discs; presence of two dark lateral bands along the sides of the head till the tympanum; flanks the same colour as the dorsum; bronze brown dorsal colouration and a pale white venter.

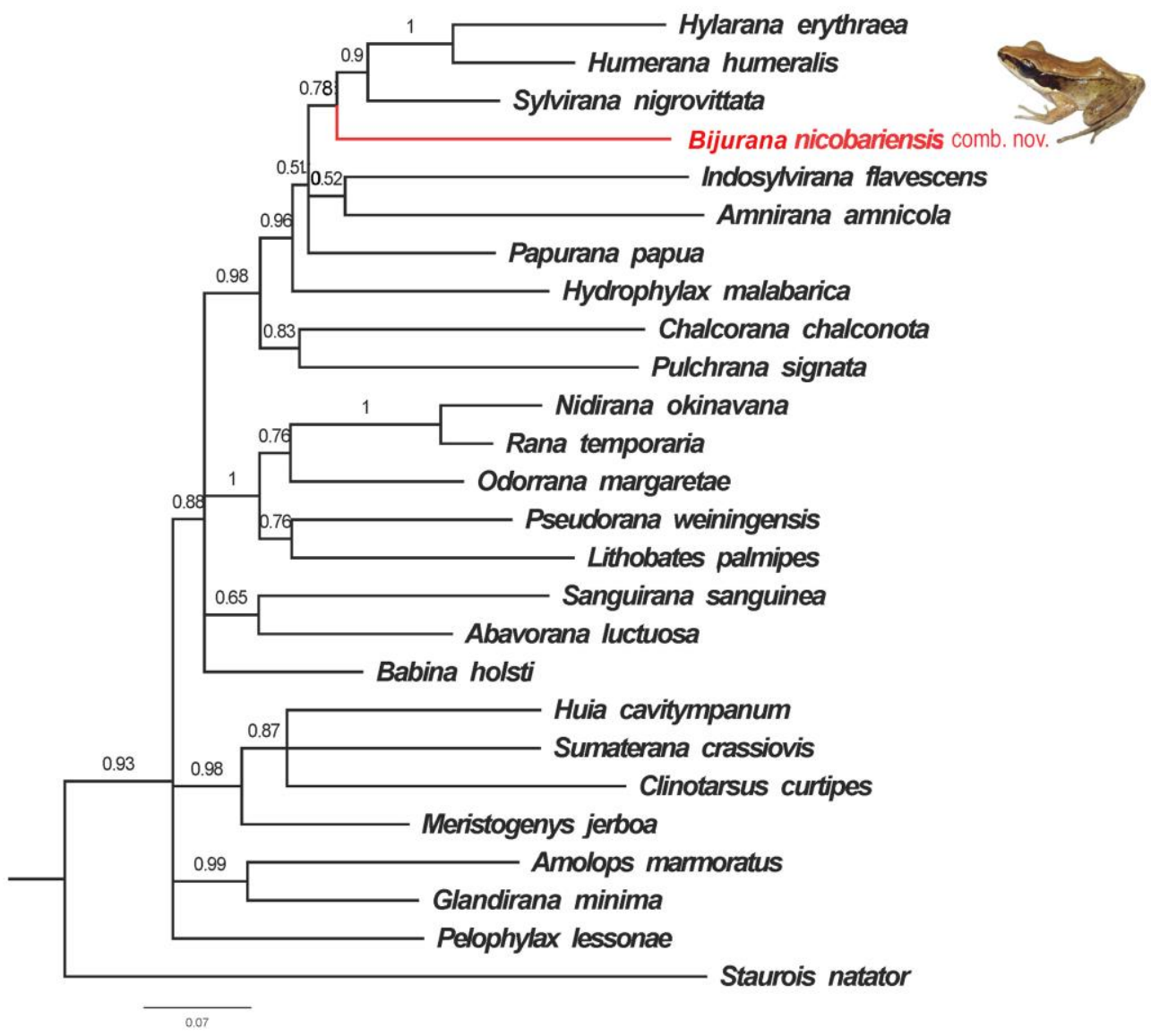

Figure 1. Bayesian phylogram showing the phylogenetic position of the new genus with respect to the type species of other recognised ranid genera (rooted with Limnonectes laticeps as the outgroup; not shown). 
Comparison. The new genus Bijurana can be distinguished from other Asian and African ranid genera by having posterior part of the abdominal skin smooth ( $v s$ granular or wrinkled in Indosylvirana, Humerana and Hylarana; smooth to granular in Amnirana, Chalcorana and Sylvirana; ventral parts of head, body and limbs: throat with indistinct glandular warts in Pterorana fide Ao et al. 2006); finger length I $>$ II ( $v s$ I $\geq$ II in Amnirana, $\mathrm{I}<\mathrm{II}$ in Chalcorana, $\mathrm{I}=\mathrm{II}$ in Hylarana); thighs with banded pattern (vs mottled/plain in Amnirana, Humerana and Papurana; plain in Hylarana and Chalcorana); thighs with longitudinal ridge-like skin-folds (vs smooth in Amnirana, Chalcorana, Humerana, Hylarana and Papurana); digital terminal disc ovoid ( $v s$ rhomboidal in Chalcorana); rictal glands on the lips well-developed ( $v s$ moderate

A

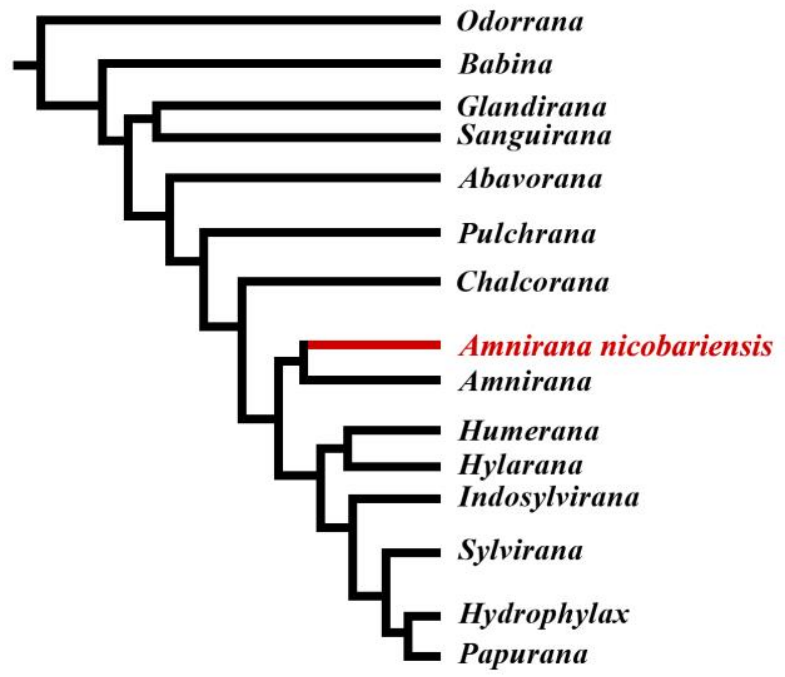

C

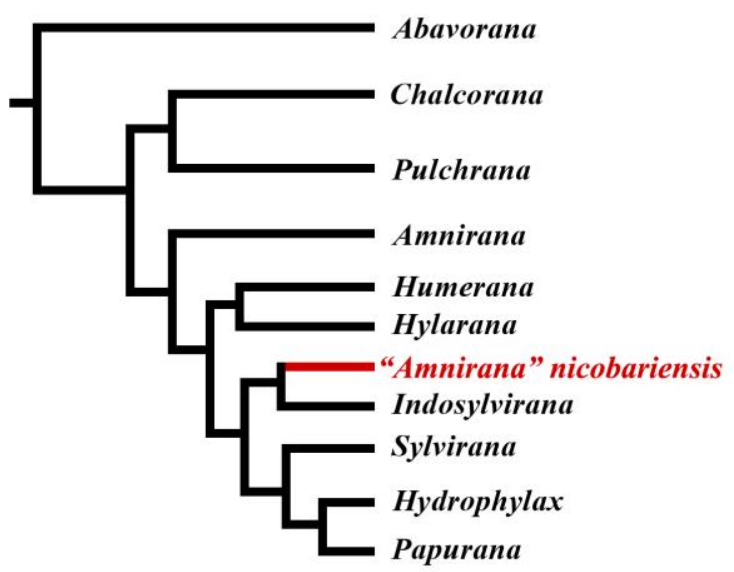

in Indosylvirana and Sylvirana; and poorly developed in Chalcorana); pronounced dorsolateral folds ( $v s$ relatively thin in Indosylvirana); flanks of the same colour as the dorsum ( $v s$ lighter than the dorsum in Indosylvirana).

Furthermore, the larvae of Bijurana gen. nov. differ from other ranid genera Chalcorana, Hylarana and also Indosylvirana by having a sparsely pigmented body ( $v s$ dark and densely pigmented in Hylarana; yellowish brown with black markings in Chalcorana); oral keratodont formula $1 / / 1+1 / 2$ [vs $1 / 3+3 / / 1+1$ or $1 / 4+4 / / 1+1$ in Chalcorana fide Inger (1985); $1+1 / / 1+1+1$ in Hylarana; $1 / 1+1 / / 1+1 / 1 / 1$ in Indosylvirana fide Hiragond \& Saidapur (1999)]; and large glandular patches absent on the larval body ( $v s$ present in Chalcorana).

B

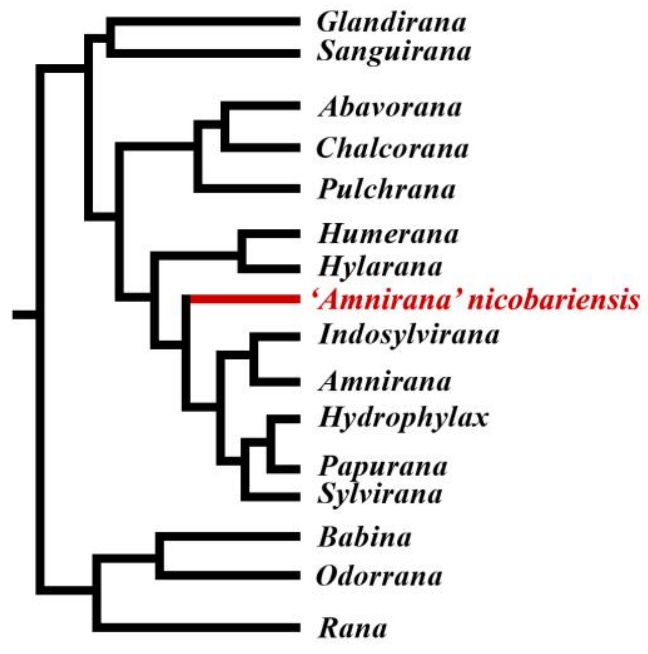

D

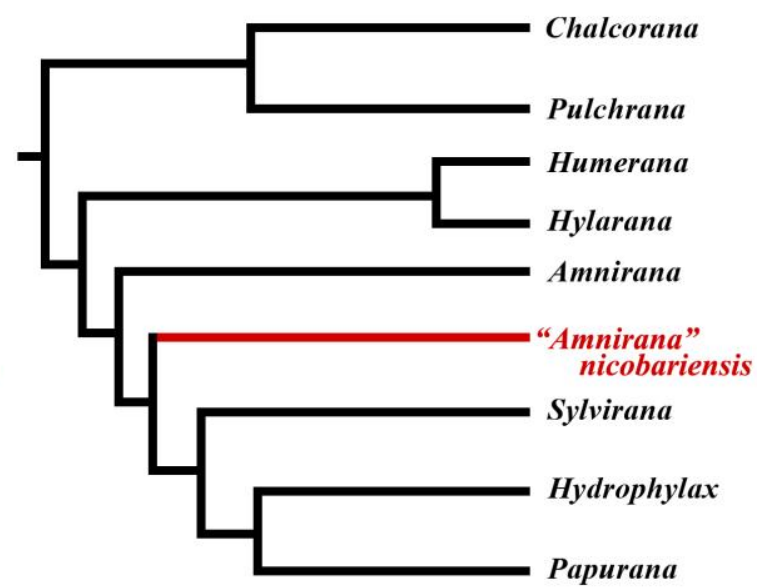

Figure 2. Tree topologies showing the phylogenetic position of Bijurana nicobariensis comb. nov. in previous studies (A) Oliver et al. (2015), (B) Chan \& Brown (2017), (C \& D) Chan et al. (2020) 
Bijurana nicobariensis comb. nov. (Tables 1-4; Figs. 1-6)

Hylorana nicobariensis Stoliczka, 1870 Rana nicobariensis - Boulenger 1885 Rana (Hylorana) nicobariensis - Boulenger 1920 Rana (Hylarana) nicobariensis - van Kampen 1923 Rana (Sylvirana) nicobariensis - Dubois 1992 Sylvirana nicobariensis - Frost et al. 2006 Hylarana nicobariensis - Che et al. 2007 Amnirana nicobariensis - Oliver et al. 2015 Amnirana (inc. sed.) nicobariensis - Chan \& Brown 2017

Indosylvirana nicobariensis — Chan et al. 2020

Syntypes $(\boldsymbol{n}=11)$. ZSIC 2783, 2785-86, 356263, 3565-70 (Fig. 5); for morphometrics of ZSIC 2783 see Table 4.

Other specimens $(\boldsymbol{n}=\mathbf{6}) . \quad$ Nicobar Archipelago, India: DOSMB 05004, 05010, 05014, 05050, 05077, 05094.

Description of a topotype. Based on DOSMB 05010 from Great Nicobar. An adult female, in a good state of preservation.

Body fairly large (SVL $52.7 \mathrm{~mm}$ ) with a relatively slender habitus; trunk a little less than half the length of the body (AG:SVL 0.42). Head large and slender (HL:SVL 0.36); longer than broad (HL:HW 1.34) with an obtusely pointed snout, slightly projecting beyond the mandible. Nostrils situated much closer to the snout tip than to the eye (EN:ES 0.61); tympanum fairly large, slightly smaller than the eye (TYD:ED 0.86). A pair of horizontally elongated, ovoid rictal glands present posterior to the jaw angle on either sides of the mandible. Upper eyelids narrower than the inter-orbital space (UEW:IO 0.82); inter-narial space wider than inter-orbital space (IO:IN 0.86).

Upper arms short (UAL:SVL 0.22); lower arms slightly longer than upper arms (LAL:SVL 0.23 ); palm slightly longer than the lower arm (PAL:LAL 1.07). Relative length of fingers: III $>$ IV $>$ I $>$ II. Thighs long, nearly half as long as the body (FEL:SVL 0.5) and slightly shorter than the tibia (FEL:TBL 0.85). Tarsus short; feet slightly longer than thighs (FEL:FOL 0.98). Toes partially webbed; webbing formula: $\mathrm{I}_{0-}$ ${ }_{0.5} \mathrm{II}_{0.5-2} \mathrm{III}_{1-2} \mathrm{IV}_{2-0.5} \mathrm{~V}$. Inner metatarsal tubercle elongated and ovoid; outer metatarsal tubercle relatively smaller. Relative lengths of toes: IV $>$ V $>$ III $>$ II $>$ I. Digit tips with ovoid and slightly expanded terminal discs with distinct circum-marginal grooves.
Dorsal skin smooth with longitudinal ridgelike skin folds on the hind-limbs; abdominal skin smooth; rectal glands well-developed near the gape and dorsolateral skin folds pronounced.

Colouration. In preservative, dorsum bronze brown without any distinct pattern; two dark brown lateral stripes commencing from the nostril till the tympanum; flanks the same colour as the dorsum; anterior ventral body and head with small brown spots on a cream coloured background; belly un-patterned, cream; under surface of the hind-limbs brownish; hind-limbs, especially thighs bear a feeble banded pattern; ventral surface of the feet dark brown.

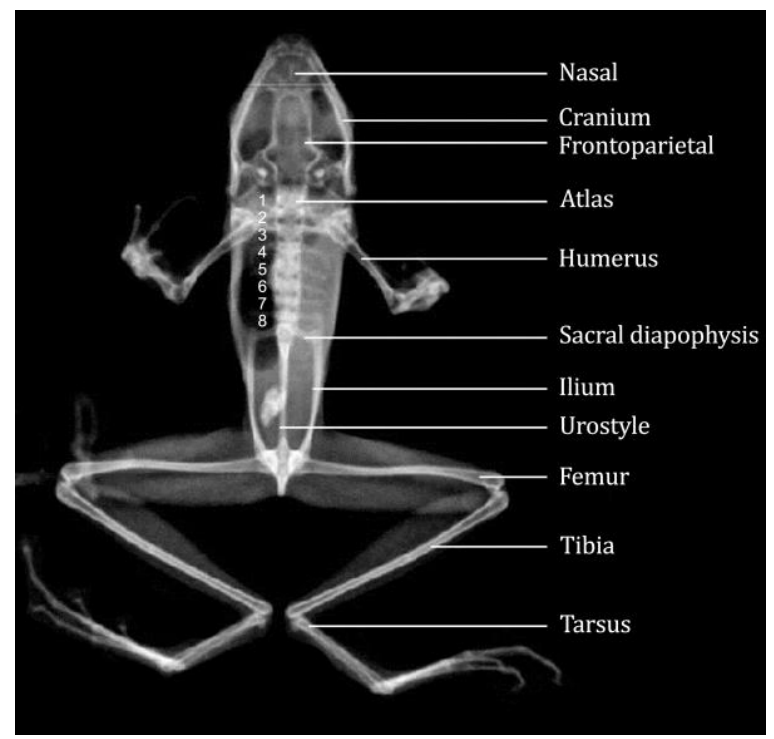

Figure 3. Osteology of an adult Bijurana nicobariensis comb. nov. (DOSMB 05050) from Little Nicobar, India.

Call description. Three calls of topotypical Bijurana nicobariensis comb. nov. were recorded (Fig. 8) from adult males at Campbell Bay and Govind Nagar, Great Nicobar during November and December in 2016 at a distance of about $1.5-2 \mathrm{~m}$ from the calling individuals (SVL 40-50 mm; not collected).

The calls comprise a series of multi-pulsed notes uttered in succession within short intervals of time. The calls recorded and described here consist of four notes. The notes lasted for a mean duration of $1.65 \pm 0.042 \mathrm{~s}$ (range 1.526$1.67 \mathrm{~s}$ ), with a mean interval of $19.43 \mathrm{~s}$ (range 18.15-21.3 s) between two consecutive notes. Each note consisted of eight pulses, each of which lasted for a mean duration of $0.12 \pm 0.005$ $\mathrm{s}$ (range $0.11-0.16 \mathrm{~s}$ ). Dominant frequency of the calls was at $3 \mathrm{kHz}$. 


\section{Plate 43}

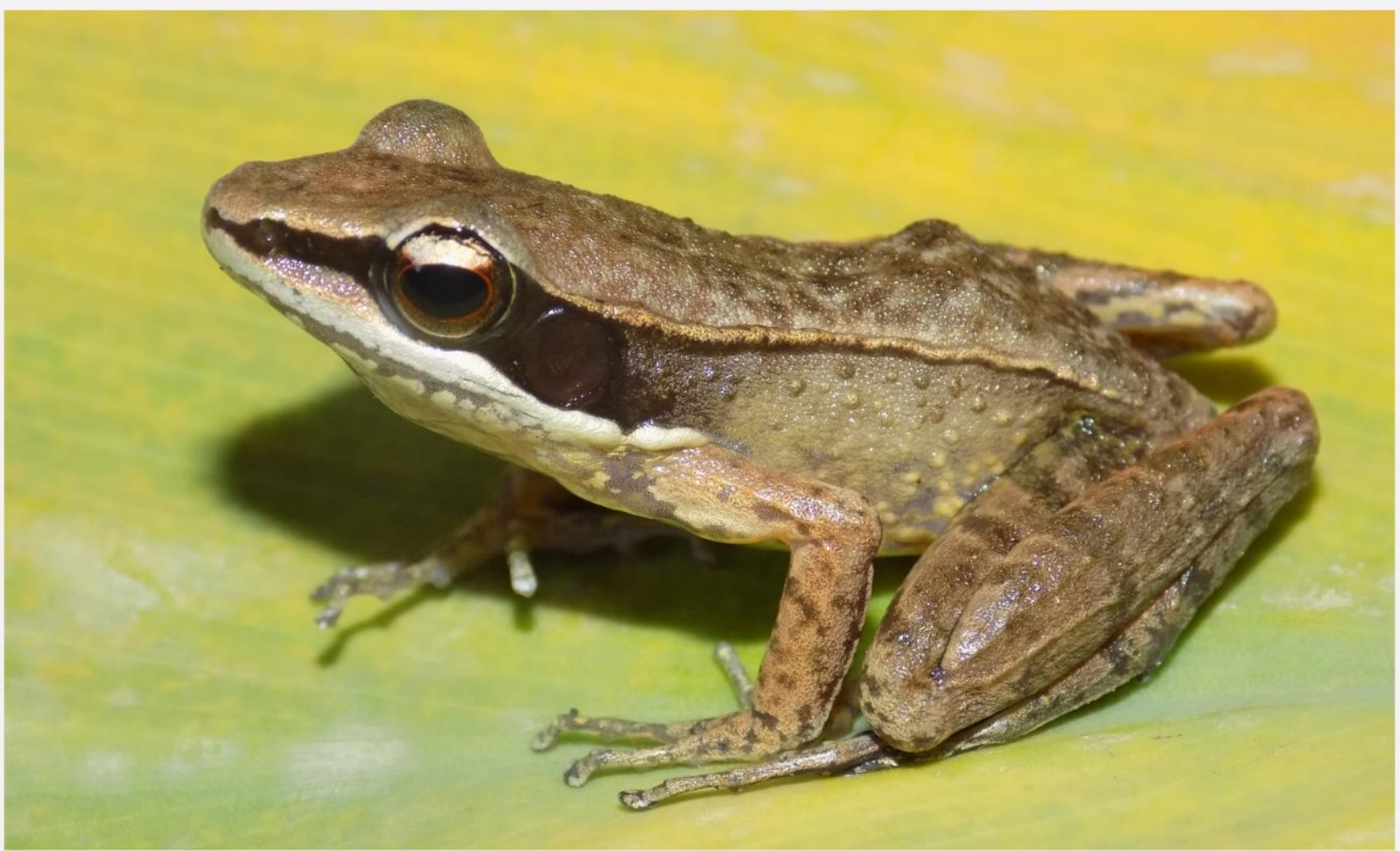

Figure 4. An adult of Bijurana nicobariensis comb. nov. (not collected) from Great Nicobar Island, India

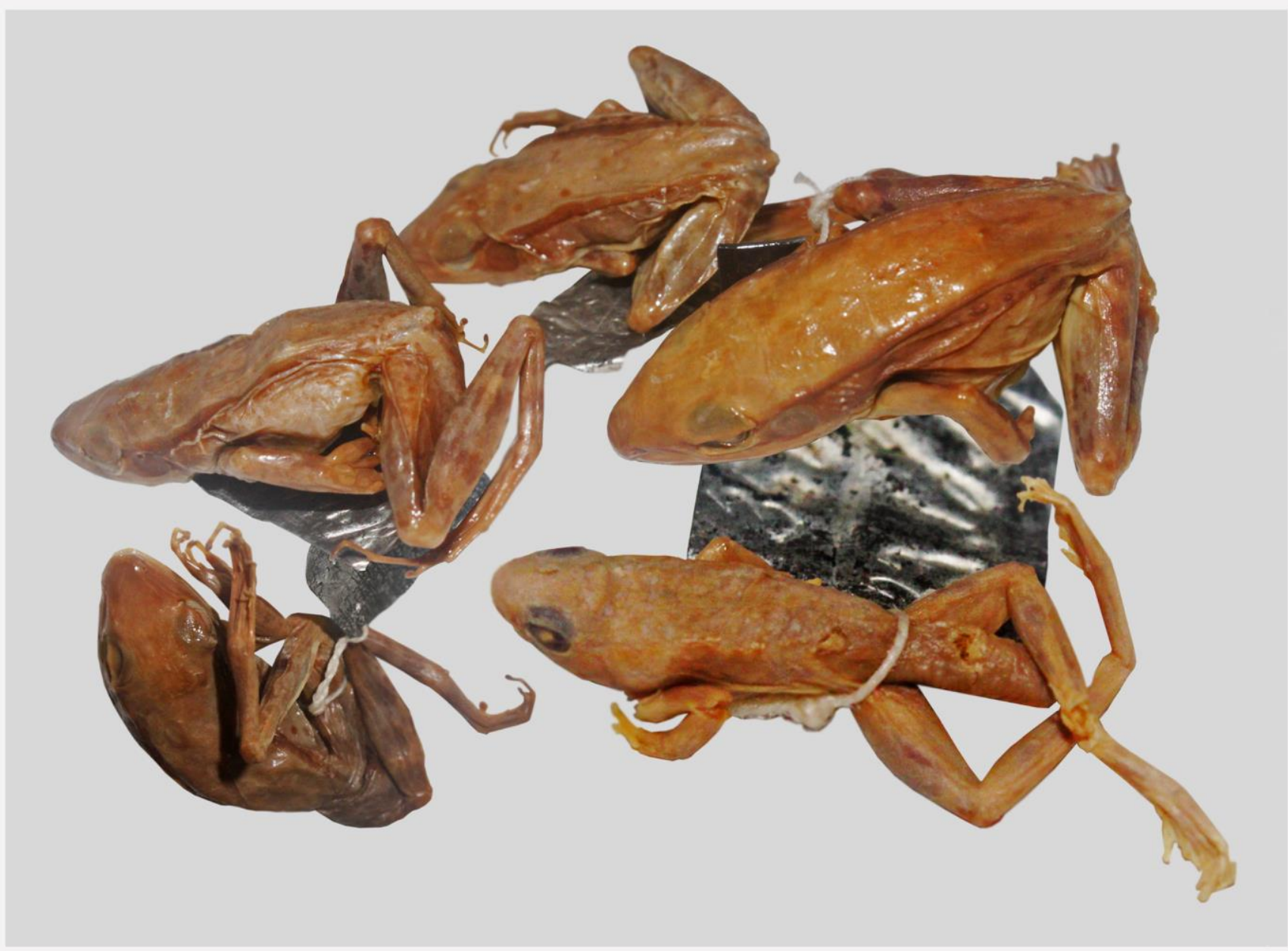

Figure 5. Part of the syntypes series (ZSIC 2783, 2785-86, 3562-63, 3565-70) of Hylorana nicobariensis Stoliczka, 1870 from "Nicobar" Island, India (not to scale). 


\section{Plate 44}

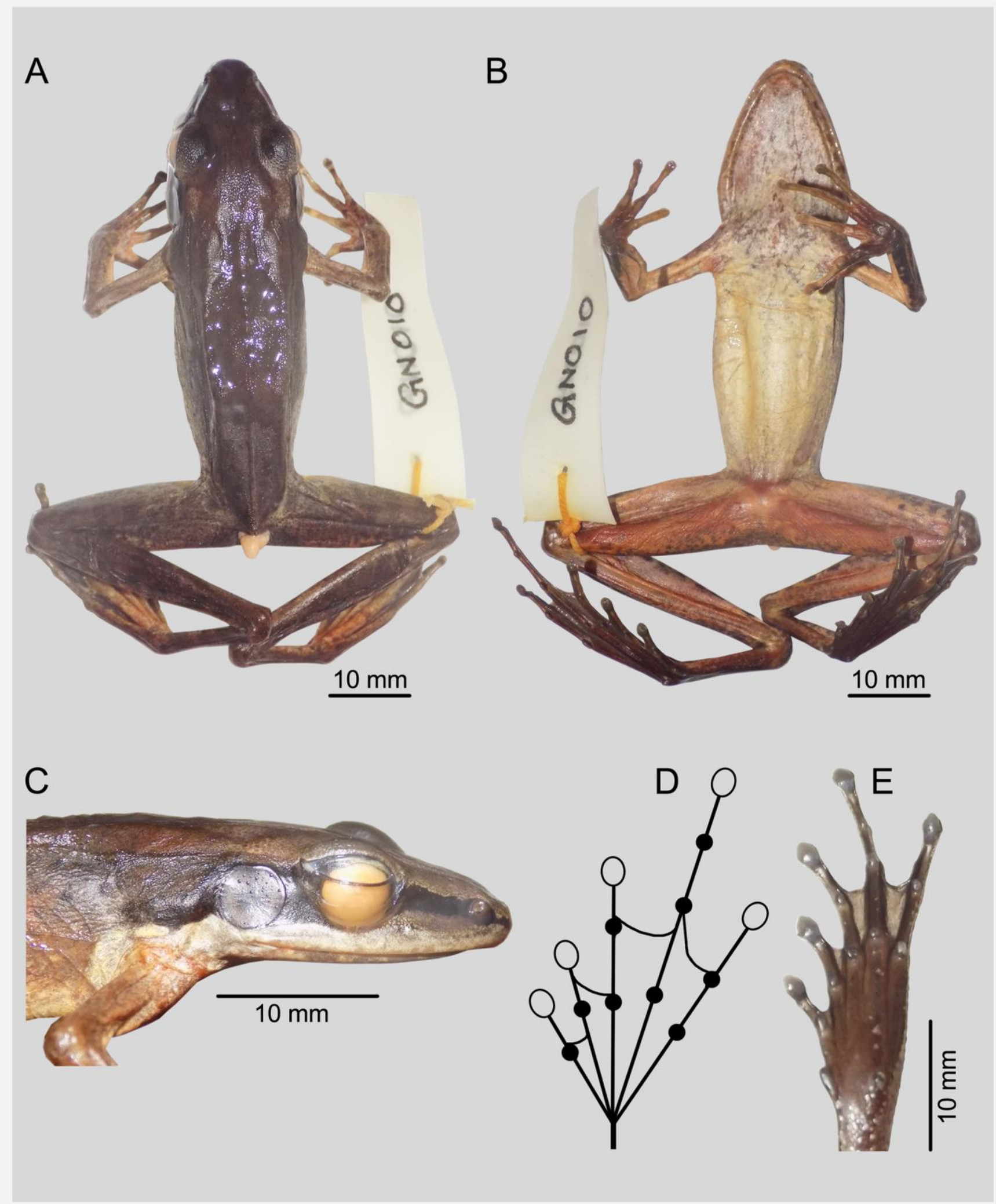

Figure 6. An adult female topotype (DOSMB 05010) of Bijurana nicobariensis comb. nov. from Great Nicobar Island, India; (A) dorsal and (B) ventral views of the body; (C) lateral view of the anterior part of the body; (D) schematic illustration of webbing of foot and (E) ventral view of the foot. 


\section{Plate 45}

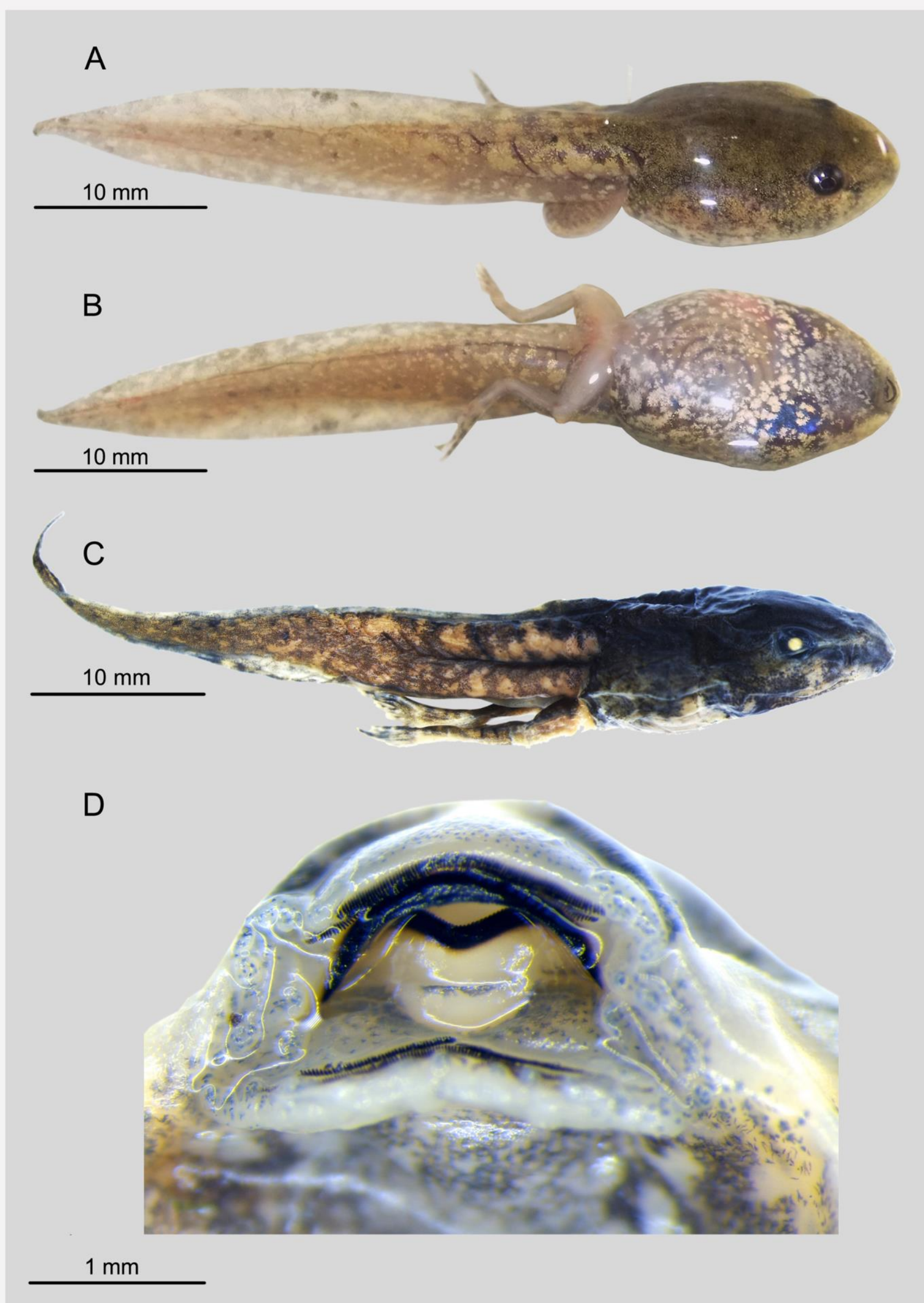

Figure 7. Tadpole of Bijurana nicobariensis comb. nov. (A) dorsal view and (B) ventral view of a live specimen (not collected); (C) lateral view of DOSMB 05079; (D) ventral view of the mouth parts. 
Table 4. Measurements (in mm) of Bijurana nicobariensis comb. nov. from the Nicobar Islands and West Java; "-_" not measured.

\begin{tabular}{|c|c|c|c|c|c|c|c|c|c|}
\hline \multirow{4}{*}{ Character } & \multicolumn{9}{|c|}{ Bijurana nicobariensis (Stoliczka, 1870 ) comb. nov. } \\
\hline & \multicolumn{3}{|c|}{ males } & \multicolumn{3}{|c|}{ females } & \multirow{3}{*}{$\begin{array}{c}\text { Syntype } \\
\text { ZSI } \\
2783 \\
\end{array}$} & \multicolumn{2}{|c|}{ males } \\
\hline & DOSMB & DOSMB & DOSMB & DOSMB & DOSMB & DOSMB & & UIMZ & UIMZ \\
\hline & 05004 & 05077 & 05094 & 05010 & 05050 & 05014 & & 0160 & 0161 \\
\hline Location & $\begin{array}{c}\text { Great } \\
\text { Nicobar }\end{array}$ & Katchall & $\begin{array}{c}\text { Car } \\
\text { Nicobar }\end{array}$ & $\begin{array}{c}\text { Great } \\
\text { Nicobar }\end{array}$ & $\begin{array}{c}\text { Little } \\
\text { Nicobar }\end{array}$ & $\begin{array}{c}\text { Great } \\
\text { Nicobar }\end{array}$ & Nicobar & \multicolumn{2}{|c|}{ West Java } \\
\hline SVL & 38.15 & 37.53 & 42.70 & 52.70 & 42.02 & 43.16 & 47.22 & 34.26 & 33.55 \\
\hline Axilla-Groin length & 12.05 & 12.82 & 16.22 & 21.98 & 14.46 & 15.95 & 16.89 & 14.69 & 13.60 \\
\hline Head length & 14.06 & 13.54 & 15.90 & 19.00 & 14.88 & 15.07 & 17.59 & 11.88 & 12.20 \\
\hline Head width & 10.04 & 10.17 & 11.55 & 14.23 & 11.72 & 12.50 & 13.62 & 8.35 & 8.22 \\
\hline Head depth & 6.05 & 4.17 & 6.21 & 7.98 & 6.82 & 8.26 & 5.90 & 4.80 & 4.47 \\
\hline Eye diameter & 4.03 & 4.04 & 3.73 & 4.67 & 4.62 & 5.04 & 5.04 & 3.72 & 3.84 \\
\hline Eye-nostril length & 3.02 & 4.32 & 4.26 & 5.33 & 4.06 & 4.26 & 5.35 & 3.39 & 3.23 \\
\hline Eye-snout length & 5.04 & 6.02 & 7.10 & 8.73 & 7.48 & 6.10 & 8.72 & 5.79 & 5.53 \\
\hline Tympanum diameter & 2.02 & 2.73 & 3.30 & 4.03 & 3.48 & 3.56 & 3.53 & 2.56 & 2.67 \\
\hline Tympanum-eye & 0.98 & 1.05 & 1.84 & 1.47 & 0.93 & 1.00 & 1.24 & 0.79 & 0.96 \\
\hline Upper eyelid Width & 2.01 & 2.68 & 2.81 & 3.34 & 2.48 & 2.67 & - & 2.15 & 2.35 \\
\hline Inter orbital distance & 2.64 & 3.00 & 4.26 & 4.07 & 3.47 & 3.00 & 5.12 & 7.85 & 7.74 \\
\hline Internarial distance & 3.15 & 2.82 & 3.09 & 4.71 & 4.10 & 3.24 & 4.27 & 2.94 & 3.08 \\
\hline Upper arm length & 8.11 & 7.98 & 9.38 & 11.70 & 8.77 & 9.03 & 9.41 & 5.68 & 5.31 \\
\hline Lower arm length & 8.12 & 6.70 & 7.91 & 12.09 & 9.53 & 9.12 & 9.97 & 5.99 & 5.51 \\
\hline Palm length & 9.02 & 10.60 & 11.03 & 12.98 & 10.83 & 11.06 & - & 8.88 & 8.84 \\
\hline Femur length & 16.07 & 17.57 & 19.73 & 26.15 & 20.62 & 20.95 & 21.98 & 17.00 & 16.78 \\
\hline Tibia length & 21.26 & 20.36 & 23.17 & 30.82 & 24.22 & 23.09 & 24.87 & 19.88 & 18.66 \\
\hline Tarsus length & 11.21 & 9.72 & 11.68 & 16.11 & 11.38 & 12.50 & 10.98 & 11.46 & 10.85 \\
\hline Foot length & 17.95 & 19.33 & 20.91 & 26.78 & 22.02 & 21.08 & 22.09 & 17.60 & 16.53 \\
\hline $\mathrm{F} 1$ & 3.06 & 4.98 & 5.44 & 7.20 & 5.30 & 6.01 & - & 3.29 & 3.19 \\
\hline $\mathrm{F} 2$ & 2.97 & 4.62 & 4.90 & 5.71 & 5.09 & 5.21 & - & 2.99 & 3.10 \\
\hline $\mathrm{F} 3$ & 4.68 & 6.24 & 7.13 & 9.79 & 8.16 & 6.57 & - & 5.24 & 5.33 \\
\hline F4 & 5.01 & 4.00 & 5.01 & 5.93 & 4.45 & 5.04 & - & 3.53 & 4.26 \\
\hline $\mathrm{T} 1$ & 3.02 & 2.30 & 3.04 & 3.89 & 3.12 & 3.53 & - & 2.37 & 2.72 \\
\hline $\mathrm{T} 2$ & 4.13 & 3.89 & 4.44 & 5.74 & 4.82 & 4.16 & - & 3.37 & 3.81 \\
\hline T3 & 6.12 & 6.00 & 6.64 & 9.25 & 7.25 & 6.57 & - & 5.52 & 7.02 \\
\hline $\mathrm{T} 4$ & 10.64 & 11.05 & 12.98 & 15.66 & 13.71 & 11.50 & - & 10.71 & 10.29 \\
\hline T5 & 7.06 & 5.73 & 7.53 & 10.16 & 8.10 & 7.06 & - & 6.07 & 7.07 \\
\hline
\end{tabular}

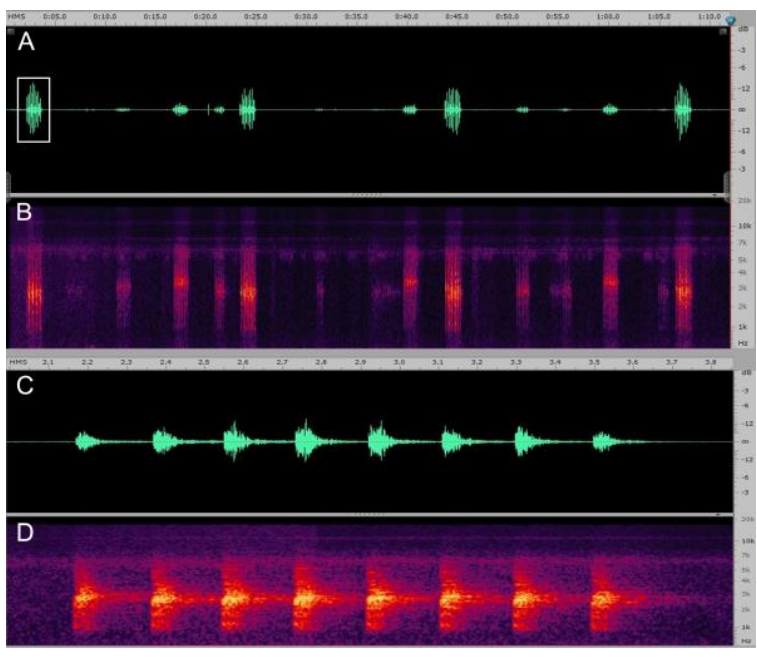

Figure 8. The call of Bijurana nicobariensis comb. nov. (A) Oscillogram and (B) spectrogram; (C \& D) magnified view of a single note composed of eight pulses.

\section{Discussion}

The generic level classification of Ranidae has undergone extensive revisions during the last few decades, with recognition of several new genera as well as new families, which were classically lumped under the cosmopolitan frog family Ranidae (Dubois 1992, Che et al. 2007, Oliver et al. 2015, Frost 2020). The systematic position of the Southeast Asian species Hylorana nicobariensis had remained uncertain, and the constantly conflicting tree topologies have been debated (Fig. 2) due to the lack of concordance (summarized by Chan et al. 2020). Although previous authors suggested various generic assignments for this taxon under Sylvirana, Hylarana, Amnirana and Indosylvirana (Frost et al. 2006; Che et al. 2007; Oliver et al. 2015; Chan et al. 2020, respectively) an unequivocal consensus still does not seem to have been reached. Perhaps it might be due to the reliance solely on genetic data in some of these studies rather than implementing integrative approaches (e.g. see Biju et al. 2016, Chandramouli et al. 2016, Garg \& Biju 2019). The allocations of Hylorana nicobariensis to each of the genera mentioned above have 
constantly been refuted by the subsequent researchers within a relatively short period of time due to the lack of concordance in their results with the earlier studies (see Introduction).

The present study has addressed this taxonomic issue within an integrated framework using a molecular phylogeny based on four genes (two nuclear and two mitochondrial) backed by morphological characters. Hence, we resorted to erecting a new generic name for Hylorana nicobariensis (=Bijurana nicobariensis comb. nov.) as a solution to this issue. We believe that this taxonomic action is the most reasonable solution considering its distinct phylogenetic position and morphological affinities, as well as the lack of an unequivocal consensus over its generic reallocations during the last few decades, resulting in nonmonophyly of those genera due to its inclusion. Similar taxonomic actions have been implemented to stabilize several cases of either non-monophyletic or uncertain generic allocations, for example, in Ansonia and Bufo (Biju et al. 2009), Philautus (Biju et al. 2010), and Pedostibes (Chan et al. 2016). Apart from its distribution on the Islands of the Nicobar archipelago, Bijurana nicobariensis comb. nov. extends further northwards and eastwards in several continental as well as insular regions of Southeast Asia, such as Sundaland and the Philippines (Malkmus et al. 2002). The complexity and cryptic diversity within the species Bijurana nicobariensis com. nov. has been indicated by some of the previous studies (Chan et al. 2020). Currently, there are several subjective synonyms for Bijurana nicobariensis comb. nov. (summarized by Frost 2020) that originate from regions far from the original type locality (Nicobars). Therefore, a critical integrative assessment is required to understand the cryptic diversity within this new genus of ranid frogs.

\section{Acknowledgements}

We thank the Department of Environment and Forests, Andaman and Nicobar Islands for permission to SRC (permit nos: CWLW/WL/134/(J)/417, CWLW/WL/134(L)/60) for conducting this study and for the infrastructure provided; K.V. Devi Prasad and the faculty of the Department of Ecology and Environmental Sciences and the Department of Ocean studies and Marine Biology, Pondicherry University for the support extended, the Mohamed bin Zayed Species Conservation fund for a grant (\#160514249) which partly facilitated this study. We also thank the former Director, K. Venkataraman (Zoological Survey of India) for granting research permission to SRC and AATA. In particular we thank K. Chandra (Director) K. C. Gopi (officer-in-charge, FPS Building, ZSI, Kolkata), K.A. Subramanian (officer-in-charge, Technical Section, ZSI) for their help throughout the permitting application process. K. Deuti, S. Raha, P.G.S. Sethy, P. Bag, and S. Debnath are also acknowledged for assisting us while examining collections in ZSI. We thank the Ministry of Research and Technology of the Republic of Indonesia and the Ministry of Environment and Forestry (KLHK) and The Directorate General of Conservation of Natural Resources and Ecosystems (KSDAE) of the Republic of Indonesia for granting research and collecting permits to AATA to survey Greater Sunda Islands. Also Enrique La Marca (University of the Andes, Venezuela), Nayana Wijayathilaka (University of Peradeniya, Sri Lanka), Philip Bowles (IUCN), and Sampath Senevirathna (University of Colombo, Sri Lanka) are acknowledged for valuable comments and reviewing the manuscript. Finally, we would like to thank J. Supriatna and the staff of the Research Center for Climate Change, University of Indonesia, for their support.

\section{Literature cited}

Ao, M., S. Bordoloi, A. Ohler, and S. Grosjean (2006). Rana khare (Kiyasetuo \& Khare, 1986): present distribution, redescription of holotype and morphology of adults and tadpoles. Alytes, 24 (1-4): 22-39.

Arifin, U., U. Smart, S.T. Hertwig, E.N. Smith, D.T. Iskandar et al. (2018). Molecular phylogenetic analysis of a taxonomically unstable ranid from Sumatra, Indonesia, reveals a new genus with gastromyzophorous tadpoles and two new species. Zoosystematics \& Evolution, 94: 163-193.

Batsch, A.J.G.K. (1796). Umriß der gesammten Naturgeschichte: ein Auszug aus den frühern Handbüchern des Verfassers für seine Vorfesungen. Jena \& Leipzig: Christian Ernst Gabler: 287pp.

Biju, S.D., I. van Bocxlaer, V.B. Giri, S.P. Loader, and F. Bossuyt (2009). Two new endemic genera and a new species of toad (Anura: Bufonidae) from the Western Ghats of India. BMC Research Notes, 2 (241): 1-10.

Biju, S.D., Y.S. Shouche, A. Dubois, S.K. Dutta, and F. Bossuyt (2010). A ground-dwelling 
Rhacophorid frog from the highest mountain peak of the Western Ghats of India. Current Science, 98: 1119-1125.

Biju, S.D., S. Garg, S. Mahony, N. Wijayathilaka, G. Senevirathne et al. (2014). DNA barcoding, phylogeny and systematics of golden-backed frogs (Hylarana, Ranidae) of the Western Ghats-Sri Lanka biodiversity hotspot, with the description of seven new species. Conributions to Zoology, 83: 269-335.

Biju, S.D., G. Senevirathne, S. Garg, S. Mahony, R.G. Kamei et al. (2016). Frankixalus, a new rhacophorid genus of tree hole breeding frogs with oophagous tadpoles. PlosOne, 11 (1): 0145727.

Bossuyt, F., R.M. Brown, D.M. Hillis, D.C. Cannatella, and M.C. Milinkovitch (2006). Phylogeny and biogeography of a cosmopolitan frog radiation: Late Cretaceous diversification resulted in continent-scale endemism in the family Ranidae. Systematic Biology, 55 (4): 579-594.

Boulenger, G.A. (1884). Diagnoses of new reptiles and batrachians from the Solomon Islands, collected and presented to the British Museum by H. B. Guppy, Esq., M.B., H.M.S. "Lark”. Proceedings of the Zoological Society of London, 1884: 210-213.

Boulenger, G.A. (1885). A list of reptiles and batrachians from the Province Rio Grande do Sul, Brazil, sent to the natural history museum. Annals and Magazine of Natural History, 5 (16): 191-196.

Boulenger, G.A. (1920). A monograph of the South Asian, Papuan, Melanesian and Australian frogs of the genus Rana. Records of the Indian Museum, 20: 1-226.

Brown, R.M. and C.D.Siler (2014). Spotted stream frog diversification at the Australasian faunal zone interface, mainland versus island comparisons, and a test of the Philippine "dual-umbilicus" hypothesis. Journal of Biogeography, 41: 182-195.

Chan K.O. and R.M. Brown (2017). Did true frogs 'dispersify'? Biology Letters, 13 (8): 20170299.

Chan, K.O., L.L. Grismer, A. Zachariah, R.M. Brown, and R.K. Abraham (2016). Polyphyly of Asian tree toads, genus Pedostibes Günther, 1876 (Anura: Bufonidae), and the description of a new genus from Southeast Asia. PLoS One, 11 (1): e0145903.

Chan, K.O., C.R. Hutter, P.L. Wood Jr., L.L. Grismer, and R.M. Brown (2020). Larger, unfiltered datasets are more effective at resolving phylogenetic conflict: Introns, exons, and UCEs resolve ambiguities in golden-backed frogs (Anura: Ranidae; genus Hylarana). Molecular Phylogenetics \& Evolution, 151 (106899): 1-16.

Chandramouli, S.R., K. Vasudevan, S. Harikrishnan, S.K. Dutta, S.J. Janani et al. (2016). A new genus and species of arboreal toad with phytotelmonous larvae, from the Andaman Islands, India (Lissamphibia, Anura, Bufonidae). ZooKeys, 555: 57-90.

Che, J., J.-F. Pang, H. Zhao, G.-F. Wu, E.-M. Zhao et al. (2007). Phylogeny of Raninae (Anura: Ranidae) inferred from mitochondrial and nuclear sequences. Molecular Phylogenetics \& Evolution, 43: 1-13.

Dubois, A. (1992). Notes sur la classification des Ranidae (Amphibiens anoures). Bulletin Mensuel de la Société Linnéenne de Lyon, 61: 305-352.

Frost, D.R. (2020). Amphibian Species of the World: an Online Reference. Version 6.1. Electronic Database accessible at <https://amphibiansoftheworld.amnh.org/i ndex.php $>$. American Museum of Natural History, New York.

Frost, D.R., T. Grant, J. Faivovich, R.H. Bain, A. Haas et al. (2006). The amphibian tree of life. Bulletin of the American Museum of Natural History, 297: 1-370.

Garg, S. and S.D. Biju (2019). New microhylid frog genus from Peninsular India with Southeast Asian affinity suggests multiple Cenozoic biotic exchanges between India and Eurasia. Scientific Reports, 9 (1): 1-13.

Goutte, S., A. Dubois, S.D. Howard, R. Marquez, J.J.L. Rowley et al. (2016). Environmental constraints and call evolution in torrent-dwelling frogs. Evolution, 70: 811826.

Hiragond, N.C. and S.K. Saidapur (1999). Description of tadpole of Rana temporalis from South India. Current Science, 76 (3): 442-444.

ICZN (1999). International Code of Zoological Nomenclature, 4th Edition. International Trust of Zoological Nomenclature, London: 306pp.

Inger, R.F. (1985). Tadpoles of the forested regions of Borneo. Fieldiana, Zoology, new series 26: 89pp.

Jelic, M., G.I.V. Klobucar, D. Dikic, P. Korlevic, D. Jelic et al. (2018). Hybridization and introgression among two alien and two native water frog species (Pelophylax spp.) in Croatia - Crna Mlaka fishpond as a species melting pot? Unpublished report.

Jiang, J.P. and K.Y. Zhou (2000). Phylogenetic relationships among Chinese ranid frogs: 
inferred from mitochondrial DNA sequences of $12 \mathrm{~s}$ and 16s ribosomal RNA genes (Anuran: Ranidae). Unpublished report.

Kakehashi, R., A. Kurabayashi, S. Oumi, S. Katsuren, M. Hoso et al. (2013). Mitochondrial genomes of Japanese Babina frogs (Ranidae, Anura): unique gene arrangements and the phylogenetic position of genus Babina. Unpublished report.

Kotaki, M., A. Kurabayashi, M. Matsui, W. Khonsue, T.H. Djong et al. (2008). Genetic divergences and phylogenetic relationships among the Fejervarya limnocharis complex in Thailand and neighboring countries revealed by mitochondrial and nuclear genes. Zoological Science, 25 (4): 381-390.

Kotaki, M., A. Kurabayashi, M. Matsui, M. Kuramoto, T.H. Djong et al. (2010). Molecular phylogeny of the diversified frogs of genus Fejervarya (Anura: Dicroglossidae). Zoological Science, 27 (5): 386-395.

Linnaeus, C. (1758). Systemae naturae per regna tria naturae, secundum classes, ordines, genera, species, cum characteribus, differentiis, synonymis, locis. Tomus I. Editio decima, Reformata. Laurentii Salvii, Holmiæ. $10^{\text {th }}$ Edition: 824.

Matsui, M., T. Shimada, W.Z. Liu, M. Maryati, W. Khonsue et al. (2006). Phylogenetic relationships of Oriental torrent frogs in the genus Amolops and its allies (Amphibia, Anura, Ranidae). Molecular Phylogenetics \& Evolution, 38 (3): 659-666.

Malkmus, R., U. Manthey, G. Vogel, P. Hoffmann, and J. Kosuch (2002). Amphibians and Reptiles of Mount Kinabalu (North Borneo). Koeltz Scientific Books, Königstein: 424pp.

Mulcahy, D.G., J.L. Lee, A.H. Miller, M. Chand, M.K. Thura et al. (2018). Filling the BINs of life: Report of an amphibian and reptile survey of the Tanintharyi (Tenasserim) Region of Myanmar, with DNA barcode data. Zookeys, 757: 85-152.

Oliver, L., E. Prendini, F. Kraus, and C.J. Raxworthy (2015). Systematics and biogeography of the Hylarana frog (Anura: Ranidae) radiation across tropical Australasia, Southeast Asia, and Africa.
Molecular Phylogenetics \& Evolution, 90: 176-192.

Perret, J.-L. (1977). Les Hylarana (Amphibiens, Ranidés) du Cameroun. Revue Suisse de Zoologie, 84: 841-868.

Posada, D. and K.A. Crandall (1998). MODELTEST: testing the model of DNA substitution. Bioinformatics, 14: 817-818.

Ronquist, F. and J.P. Huelsenbeck (2003). MrBayes 3: Bayesian phylogenetic inference under mixed models, Bioinformatics, 19 (12): 1572-1574.

Savage, J.M. and W.R. Heyer (1997). Digital webbing formulae for anurans: a refinement. Herpetological Review, 28 (3): 131-131.

Shimada, T., M. Matsui, P. Yambun, and A. Sudin (2011). A taxonomic study of Whitehead's torrent frog, Meristogenys whiteheadi, with descriptions of two new species (Amphibia: Ranidae). Zoological Journal of the Linnaean Society, 161: 157-183.

Stoliczka, F. (1870). Observations on some Indian and Malayan Amphibia and Reptilia. Proceedings of the Asiatic Society of Bengal, 1870: 103-109.

Sumida, M., H. Ueda, and M. Nishioka (2003). Reproductive isolating mechanisms and molecular phylogenetic relationships among Palearctic and Oriental brown frogs. Zoological Science, 20 (5): 567-580.

Tamura, K., G. Stecher, D. Peterson, A. Filipski, and S. Kumar (2013). MEGA6: Molecular Evolutionary Genetics Analysis version 6.0. Molecular Biology \& Evolution, 30 (12), 2725-2729.

Uetz, P., S. Cherikh, G. Shea, I. Ineich, P.D. Campbell et al. (2019). A global catalog of primary reptile type specimens. Zootaxa, 4695 (5): 438-450.

van Kampen, P.N. (1923). The Amphibia of the Indo-Australian Archipelago. Leiden: E.J. Brill Ltd.

Yuan, Z-Y., W-W. Zhou, X. Chen, N.A. Poyarkov, Jr., H-M. Chen et al. (2016). Spatiotemporal diversification of the true frogs (Genus Rana): a historical framework for a widely studied group of model organisms. Systematic Biology, 65 (5): 824-842.

Appendix I. Other specimens examined

Bijurana nicobariensis (2 ex.): Indonesia: Java: UIMZ 0160, 0161.

Chalcorana chalconota (2 ex.): Indonesia: Bali: UIMZ 0052, 0168.

Chalcorana sp. (2 ex.): India: Great Nicobar: DOSMB 05013, 05014.

Hylarana erythraea (4 ex.): Nicobar Islands: DOSMB 05005, 05006, 05076, 05095. 
- blank page - 